\title{
The Phytoseiidae (Acarina: Mesostigmata) of Puerto Rico ${ }^{1,2}$
}

\author{
H. A. Denmark and Martin H. Muma
}

\begin{abstract}
This is a faunal summary of the phytoseiids of Puerto Rico in which three new species are described: Typhlodromips plumosus, Typhlodromalus higuilloae, and Amblydromella deleoni. Fourteen other species are recorded from the island for the first time, bringing the total to 48 species.
\end{abstract}

\section{INTRODUCTION}

Several workers $(23,5,14)$ have previously described or recorded Phytoseiidae from Puerto Rico and the species recorded here for the first time are collated with earlier records in table 1 . Fox (23) was concerned only with possible rat parasites in his study and described three new species. Chant (5) merely recorded two species from material deposited in the U. S. National Museum. However, De Leon (14), who spent two weeks on the island in 1963 specifically collecting plant-inhabiting mites, recorded 24 species, 14 of which he described as new. Muma collected phytoseiids in Puerto Rico for two weeks in 1968 and 1969, and recorded 13 species, three of which are described here. A total of 48 species of phytoseiids are now known to occur on the island.

De Leon collected 16 species not collected by Muma who collected 11 species not collected by De Leon. This suggests that phytoseiid populations are extremely unstable, as indicated by Muma, et al. (47), and that additional plant inhabiting species will be found on the island. Further, neither De Leon nor Muma collected extensively on grasses and related plants or from ground surface litter, thus many species restricted to these strata were missed.

The predatory nature of most phytoseiids is well known, and their food habits were summarized by Muma (43). Although biological and ecological

1 Manuscript submitted to Editorial Board August 1, 1974.

${ }^{2}$ Contribution No. 266, Bureau of Entomology, Division of Plant Industry, Florida Department of Agriculture and Consumer Services, Gainesville, Florida 32602.

3 Chief of Entomology, Bureau of Entomology, Division of Plant Industry, Florida Department of Agriculture and Consumer Services, Gainesville, Florida, and Entomologist Emeritus, University of Florida and Research Associate, Florida State Collection of Arthropods, BE, DPI, FDACS, Gainesville, Florida. The authors are grateful to Mr. Silverio Medina Gaud, Agricultural Experiment Station, University of Puerto Rico, for reviewing the manuscript. 
studies have not been conducted on most phytoseiids found in Puerto Rico, certain species have been studied in other areas. Such studies are cited in the specific discussions below.

Fox's type material is deposited in the collections of the School of Tropical Medicine in San Juan, Puerto Rico (STM). De Leon's holotypes are deposited in the Museum of Comparative Zoology, Harvard University, Cambridge, Massachusetts (MCZ) and the U. S. National Museum of Natural History, Washington, D. C. (NMNH). The types of the species described here are deposited in the Florida State Collection of Arthropods, Gainesville, Florida (FSCA).

Our systematics and terminology are those utilized by Muma, et al. (47) and Tuttle and Muma (55). Mites were mounted in a modified Hoyer's solution and examined at magnifications varying from $500 \times$ to $1000 \times$.

AMBLYSEIINAE Muma

\section{Genus Phytoseiulus Evans}

Phytoseiulus Evans, 1952:397 (22). Type: Laelaps macropilis Banks 1905 (2), by designation, Evans (22).

This genus of six species probably is world-wide in distribution and common in the Caribbean area. Only the type species is known from Puerto Rico.

\section{Phytoseiulus macropilis (Banks)}

Laelaps macropilis Banks 1905:139 (2).

Hypoaspis macropilis, Banks 1915:85 (3).

Phytoseiulus speyeri Evans, 1952:398 (22).

Phytoseiulus macropilis, Cunliffe and Baker 1953:23 (6).

Diagnosis: Females of $P$. macropilis can be separated from persimilis Athias-Henriot by the presence of one pair of preanal setae and macroseta Sti IV weakly plumose.

Discussion: Smith and Summers (53), Prasad (49), and Muma (44) have discussed the food habits and biological control potential of this species. It was collected in Puerto Rico by De Leon at Santurce on Desmodium purpureum. Muma took it in Puerto Rico: 3 females, 1 male, Río Piedras, Agr. Exp. Sta. greenhouse, 28-VIII-1968, on Cedrela odorata feeding on $T$. tumidus; 2 females, 1 nymph, Naranjito, Barranquitas Rd., Km 15, 29VIII-1968, on Ipomoea rubra; 6 females, 1 male, 12 nymphs, Ponce, Adjuntas Rd., Km 28.6, 4-IX-1968, on Ipomoea sp.; 2 nymphs, Río Piedras, Agr. Exp. Sta., 28-VIII-1968, on unknown host; 3 females, 2 males, Mameyes to El Yunque, Rd. 191, 1-IX-1968, on Ipomoea sp.; 1 female, Doña Juana Forest, recreation area entrance, 29-VIII-1968, on Elephantopus mollis; 2 
Table 1.-Phytoseiidae knoun to occur in Puerto Rico

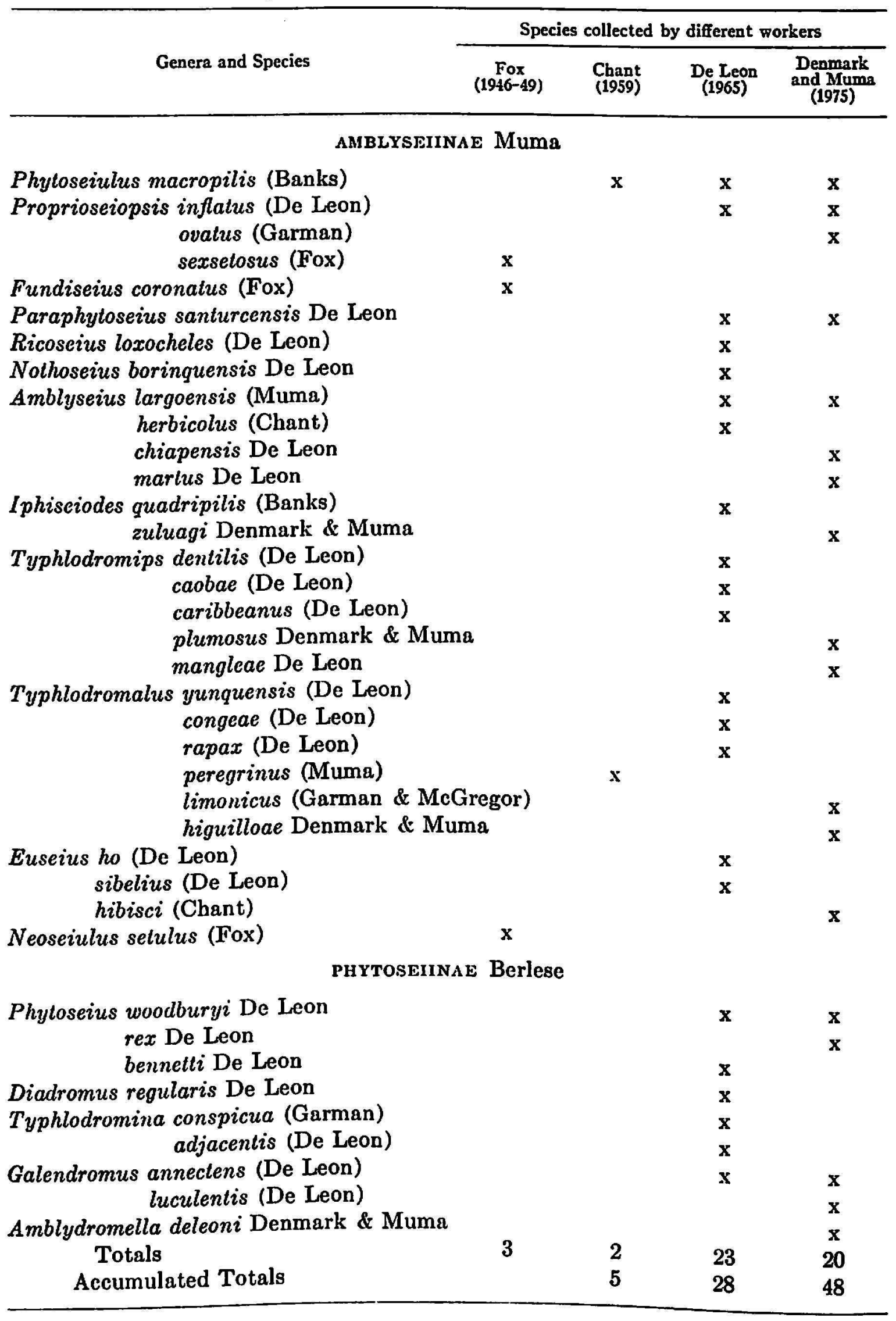


females, Hato Rey, 24-VIII-1968, on Convolvulus sp.; 1 nymph, Mayagüez, 26-V-1969, on unknown host; 1 female, El Yunque, 7-V-1969, on wild sweet potato vine; 2 females, southwest of Naval Station along Rd. 973, off Rd. 3, 31-VIII-1968, on Ipomoea rubra.

\section{Genus Proprioseiopsis Muma}

Proprioseiopsis Muma, 1961:277 (38) (type only); Muma and Denmark, 1968:231 (45). Type: Typhlodromus (Amblyseius) terrestris (Chant), 1959, by designation, Muma (39). Amblyseiulus Muma, 1961:278 (40); De Leon, 1966:83 (17). Amblyseius Berlese, Schuster, and Pritchard, $1963: 255$ (52) (in part).

This genus is world-wide in distribution and common in the Caribbean area. There are approximately 40 species in this genus, most of which can be grouped by spermathecal shape.

\section{Proprioseiopsis inflatus (De Leon), new combination}

Amblyseius inflatus De Leon, 1965:131 (14).

Diagnosis: This species resembles $P$. tubulus Muma, but $\mathrm{L}_{4}, \mathrm{~L}_{8}$ and $\mathrm{M}_{2}$ are longer and $\mathrm{L}_{3}$ is much shorter than in tubulus.

Type Female: Sabana Grande, Puerto Rico, 30-VIII-1963, D. De Leon, on Clidemia strigillosa; (MCZ).

Discussion: Female paratypes were taken with the holotype. We have one additional record: 1 female, Río Piedras, 21-VIII-1968, on Aneilema sp. leaf.

Proprioseiopsis sexsetosus (Fox), new combination

Borinquolaelaps sexsetosus Fox, $1949: 39$ (25).

Typhlodromus (Amblyseius) sexsetosus, Chant, 1959:103 (5) (dubious species).

Diagnosis: The type of this species is obviously a Proprioseiopsis but needs clearing and remounting. Fox's illustration resembles $P$. tubulus Muma, of which it may be a synonym. It is maintained separately until the type can be studied adequately.

TyPe Frmale: San Juan (Santurce), 17-IX-1946, on Rattus norvegicus; (STM).

Discussion: Known only from the type specimen.

Proprioseiopsis ovatus (Garman)

Amblyseiopsis ovatus Garman, 1958:78 (27).

Amblyseius ovatus, Chant, 1959:90 (5).

Proprioseiopsis ovatus, Tuttle and Muma, 1973:11 (55). 
Trpe Frmale: Grants Pass, Oregon, 22-X-1952, on ladino clover; (NMNH Slide No. 7, Lot 52-12630).

Discussion: Recorded from Puerto Rico for the first time: 3 females, southwest of Naval Station along Rd. 973, off Rd. 3, 31-VIII-1968, on Ipomoea rubra.

\section{Genus Fundiseius Muma and Denmark}

Athiasia Muma and Denmark, 1968:233 (45) (Preoccupied by Athiaseius Wainstein, 1962:17 (57).)

Fundiseius Muma, Denmark, and De Leon, 1970:71 (47). Type: Typhlodromips cesi Muma 1965 (41), by designation, Muma and Denmark, 1968 (45).

There are presently six species in this genus: four in Florida, one in Puerto Rico, and one in Argentina.

\section{Fundiseius coronatus (Fox), new combination}

Borinquolaelaps coronatus Fox, 1946:450 (23).

Typhlodromus (Amblyseius) coronatus, Chant, 1959:103 (5) (dubious species).

Diagnosis: $F$. coronatus is similar to hystrix (Muma) but differs by the reticulated dorsal scutum and the shorter $L_{1}$ and leg IV macrosetae.

Type Female: Camp O'Reilly, Gurabo, Puerto Rico, 31-I-1946, Irving Fox, from Rattus norvegicus; (STM).

Discussion: Our records include: 3 females, 2 males, El Yunque, Rd. Luquillo-Caribbean National Forest, Km 5.5, 26-VIII-1968, on turk's cap; 1 male, El Yunque, $\mathrm{Km} 11.0$ from Palmer, 10-V-1969, on hibiscus leaves; 1 female, El Yunque, $\mathrm{Km}$ 6.6 from Palmer, 10-V-1969, on unknown host.

\section{Genus Paraphytoseius Swirski and Shechter}

Paraphytoseius Swirski and Shechter, 1961:113 (54). Type: Paraphytoseius multidentatus Swirski and Shechter, by original designation and monotypy.

Ptenoseius Pritchard and Baker, 1962:295 (50); Shuster and Pritchard, 1963:198 (52). (Type: Amblyseius (Ptenoseius) horrifer Pritchard and Baker by original designation and monotypy, De Leon, 1965:130 (14).)

Paraphytoseius multidentatus Swirski and Shechter has been taken in Hong Kong and Africa, and P. santurcensis in Puerto Rico and Trinidad.

\section{Paraphytoseius santurcensis De Leon}

Paraphytoseius santurcensis De Leon, 1965:130 (14).

Diagnosis: $P$. santurcensis is similar to multidentatus Swirski and Shechter but differs by having 10 pairs of small pores on the dorsal scutum 
and the margin, notched near $\mathrm{L}_{4} . \mathrm{L}_{1}, \mathrm{~L}_{4}, \mathrm{~L}_{6}$, and $\mathrm{M}_{2}$ are longer and genu IV with two short rod-shaped setae in santurcensis.

Trpe Female: Santurce, 5-IX-1963, D. De Leon, on Hibiscus tiliaceus; (MCZ).

Discussion: De Leon collected three males and six females with the holotype and one female on Hura crepitans. He reported it common on Hibiscus tiliaceus with 10 or more per leaf. The male was observed mating on the back of the female, whereas other species of phytoseiids mate with the male beneath the female and ventral side up. We have one additional record: 1 female, 1 nymph, San Sebastian, Rd. 112, Km 7.0, 15-V-1969, on "higuillo" leaves.

\section{Genus Ricoseius De Leon}

Amblyseius (Ricoseius) De Leon, 1965:128 (14).

Ricoseius, Muma and Denmark, 1968:233 (45). Type: Amblyseius (Ricoseius) loxocheles De Leon, by monotypy.

This species has been taken in Puerto Rico, Brazil, and Florida. The Florida specimens were feeding on rust-infected seagrape leaves, Uredo coccolobae.

\section{Ricoseius loxocheles (De Leon)}

Amblyseius (Ricoseius) loxocheles De Leon, 1965:128 (14). Ricoseius loxocheles, Denmark and Muma, 1970:119 (20).

Diagnosis: $R$. loxocheles differs from all other known phytoseiids by having elongate whip-like capitate dorsal scutal setae, three pairs of sublateral setae, large multidentate chelicerae, four pairs of ventrolateral setae and a curious combination of capitate and setiform macrosetae on leg IV.

Type Female: Cayey Mountain, 28-VIII-1963, D. De Leon, on Cordia alliodora; (MCZ).

\section{Genus Nothoseius De Leon}

Nothoseius De Leon, 1965:127 (14). Type: Nothoseius borinquensis De Leon, 1965: 127 (14), by original designation.

This species has been collected in Puerto Rico and Jamaica.

Nothoseius borinquensis De Leon

Nothoseius borinquensis De Leon, 1965:128 (14).

Diagnosis: The females have a transparent crescent-shaped body attached by anterior and posterior ends at mid-line or dorsal scutum. No other known phytoseiid has this unique structure. Ventral surface with usual family characteristics. 
Type Frmale: Salinas, 28-VIII-1963, D. De Leon, on Rhynchosia reticulata; (MCZ).

Discussion: Additional records: Cayey Mountain on Cordia sulcata and De Leon (1965) collected a female with an egg containing an almost fully developed larva.

\section{Genus Amblyseius Berlese}

Amblyseius Berlese, 1914:143 (4); Muma, 1961:287 (39); De Leon, 1966:88 (17). Type: Zercon obtusus Koch, 1839 (31), by indication of Berelese (1914).

\section{Amblyseius largoensis (Muma)}

Amblyseiopsis largoensis Muma, 1955:266 (38).

Amblyseius neolargoensis van der Merwe, 1965:59 (37). Amblyseius largoensis, Muma, Denmark, and De Leon, 1970:69 (47).

Diagnosis: $A$. largoensis resembles deleoni Muma and Denmark from which it is distinguished by the parallel-sided spermathecal cervix and slight difference in the spermatodactyl.

Type Female: Key Largo, Florida, XII-1952, M. H. Muma, from key lime leaves; (NMNH).

Discussion: This species was taken by De Leon at Santurce on Cocos nucifera, Mangifera indica, Calophyllum calaba, and Hura crepitans; at Ponce on Spondias dulcis; at Salinas on Cordia sebestena. Our records include: 1 male, Isabela, Exp. Sub-sta., 19-V-1969, on mango leaves; 2 females, Isabela Agr. Exp. Sub-sta., 18-V-1969, on Hibiscus sp.; 4 females, Isabela, Exp. Sub-sta., 18-V-1969, on mango; 1 female, Isabela Agr. Exp. Substa., 18-V-1969, on tropical almond; 1 male, El Collao, Cayey-Salinas Rd., Km 71.0, 27-VIII-1968, on turk's cap; 3 females, Hato Rey, 24-VIII-1968, on Convolvulus sp.; 4 males, Hato Rey, 24-VIII-1968, on Hibiscus sp.; 3 females, 2 males, Hato Rey, 25-VIII-1968, on unknown host; 2 females, 2 males, Bayamon Cruce Dávila, Km 52 San Juan Rd. 2, 13-V-1969, on unknown host; 1 male, Río Piedras, Agr. Exp. Sta., 23-VIII-1968, on unknown host; 1 female, 1 male, Río Piedras, Agr. Exp. Sta., 30-VIII-1968, on croton leaf; 7 females, 6 males, 2 nymphs, Fortuna Agr. Exp. Sub-sta. 27 -VIII-1968, on mango.

\section{Amblyseius herbicolus (Chant)}

Typhlodromus (Amblyseius) herbicolus Chant, 1959:84 (5).

Diagnosis: $A$. herbicolus is near perlongisetus (Berlese) but differs by having a pair of elliptical pores on the ventrianal scutum and the overall shape of the ventrianal scutum. 
Type Female: Portugal (taken at Boston), 13-VIII-1955, J. D. Crump, on bromeliad; (NMNH).

Discussion: This species was taken in Puerto Rico by De Leon at Santurce on Tabebuia sp.; Río Piedras on Faramea occidentalis, Lagerstroemia speciosa, Lantana involucrata, Psidium guajava, and Palicourea crocea; at Sabana on Andria inermis.

\section{Amblyseius chiapensis De Leon}

Amblyseius chiapensis De Leon, 1961:86 (12).

Diagnosis: $A$. chiapensis resembles triplaris De Leon, but differs in having one denticule instead of three on the movable digit and in the shape of the spermatodactyl.

Type Female: Tuxtla Gutiérrez, Chiapas, Mexico, 18-I-1957, De Leon, on Ceiba pentandra; (MCZ).

Discussion: Our records include the following: 1 female, MayagüezMaricao, Rd. 105, $\mathrm{Km}$ 12.7, 3-IX-1968, on unknown host; 1 female, Mayagüez, 29-V-1969, on Muntingia calabura leaves.

\section{Amblyseius martus De Leon}

Amblyseius martus De Leon, 1966:92 (17).

Diagnosis: $A$. martus is similar to aerialis (Muma) but differs in having $\mathrm{L}_{1}, \mathrm{M}_{2}$, macrosetae on leg IV, and cervix shorter. $A$. martus also has multiple spermathecae on both sides.

Type Female: Natural Reserve, Bartica, Guyana (British Guiana), 28-X-1963, D. De Leon, on Swartzia leiocalycina; (MCZ).

Discussion: Our records include the following: 1 female, 1 male, El Yunque, 7-V-1967, on roseapple leaves; 1 female, El Yunque, $\mathrm{Km} 5.3$ from Palmer, 10-V-1969, on taro leaves; 2 males, Río Piedras, 9-V-1969, on Calophyllum brasiliense var. antillanum; 1 nymph, Río Piedras, 8-V-1969, on hibiscus leaves; 2 females, Río Piedras, Agr. Exp. Sta., 23-VIII-1968, on Philodendron sp.; 2 females, Río Piedras, Agr. Exp. Sta., 7-V-1969, on unknown host; 5 females, Río Piedras, Agr. Exp. Sta., 23-VIII-1968, on unknown host; 1 female, Rd. 185, Km 2.6 north of Rd. 3, 1-IX-1968, on Lantana sp.; 1 female, 1 male, Utuado-Arecibo, $\mathrm{Km}$ 63.4, 4-IX-1968, on unknown host; 2 females, 1 male, Trujillo Alto, 5-IX-1969, on Passiflora sp.; 1 female Mayagüez, 26-V-1969, on unknown host; 1 female, El Collao, Cayey-Salinas Rd. Km 71.0, 27-VIII-1968, on turk's cap; 1 female, southwest of Naval Station, Rd. 973 off Rd. 3, 31-IX-1968, on castor bean; 1 female, 1 male, Sabana Grande on Rd. 120, Km 18.0, 17-V-1969, on Citrus sp.; 1 female, 1 male, Ponce-Adjuntas Rd. Km 17.3, 4-IX-1968, on Cissus sp.; 1 female, 2 males, 1 nymph, Caguas-Cidra, Rd. 172, 22-VIII, 1968, on Hibiscus sp.; 3 females, 1 male, Isabela, 15-V-1969, on mango leaves. 
Genus Iphiseiodes De Leon

Iphiseiodes De Leon, 1966:84 (17); Muma, Denmark, and De Leon, 1970:70 (47); Denmark and Muma, 1972:22 (20). Type: Sejus quadripilis Banks, by designation of De Leon, 1966.

There are four described and one undescribed species in this genus. The genus has been reported in Costa Rica, Florida, Honduras, Jamaica, Mexico, Puerto Rico and Trinidad.

\section{Iphiseiodes quadripilis (Banks)}

Sejus quadripilis Banks 1905:138 (2).

Iphiseiodes quadripilis, De Leon, 1966:84 (17).

Dragnosis: $I$. quadripilis is near zuluagi Denmark and Muma, but the spermathecal atrium is not enlarged, $\mathrm{M}_{3}$ is minute and macrosetae of leg IV and $\mathrm{L}_{8}$ are spatulate and not knobbed as in zuluagi.

Female Holotype: Eustis, Florida on Citrus sinensis leaves; (NMNH).

Discussion: De Leon collected this species at Santurce on Laguncularia racemosa and at Río Piedras on a meliaceous tree.

\section{Iphiseiodes zuluagi Denmark and Muma}

Iphiseiodes zuluagi Denmark and Muma, 1972:23 (19).

Diagnosis: I. zuluagi is near quadripilis (Banks) but $\mathrm{L}_{8}$ and macrosetae of leg IV are distinctly knobbed in zuluagi. The spermathecal atrium is enlarged in zuluagi.

Female Holotype: Palmira, Colombia, 20-V-1969, Ivan Zuluaga, on Citrus sinensis; (FSCA).

Discussion: Our records include the following: 1 female, Lajas-San Germán, Rd. 101, Im 26.9, 3-IV-1968, on "espino" tree; 1 female, Río Piedras, Agr. Exp. Sta., 30-VIII-1968, on croton leaf; 3 females, 1 male, Isabela, 19-V-1969, on mango leaves; 1 female, Mayagüez, Rd. 106, $\mathrm{Km}$ $5.3,27-V-1969$, on coffee leaves; 2 females, 1 male, Río Piedras, 9-V-1969, on Calophyllum brasiliense var. antillanum; 1 female, El Yunque $\mathrm{Km} 5.5$ from Palmer, 10-V-1969, on taro leaves; 2 females, Río Piedras, 9-V-1969, on Crescentia sp., calabash-tree; 3 females, 1 male, Trujillo Alto, 9-V-1969 on Passiflora sp.; 1 female, 1 nymph, Gurabo, 7-V-1969, on leaves of Pterocarpus indicus; 1 nymph, Río Piedras, 8-V-1969, on croton leaves; 1 female, El Yunque, 7-V-1969, on wild sweet potato vine; 2 females, Río Piedras,. 8-V-1969, on leaves of hibiscus: 9 females, 1 male, Río Piedras, 8-V-1969, on Malphigia punicifolia and Malphigia glabra.

\section{Genus Typhlodromips De Leon}

Typhlodromopsis De Leon, 1959:113 (9) (in part, not typical species). Typhlodromips De Leon, 1965:23 (16). Type: Typhlodromopsis simplicissimus De Leon, 1965 , by original designation. 


\section{Typhlodromips dentilis (De Leon)}

Typhlodromus dentilis De Leon 1959:105 (8). Amblyseius (Typhlodromopsis) dentilis, Muma, 1961:287 (39). Typhlodromips dentilis, Muma, Denmark, and De Leon, 1970:82 (47).

Diagnosis: T. dentilis is closely related to arenillus Denmark and Muma but has the spermathecal cervix 20 times longer than wide and about 10 times longer than wide in arenillus. $T$. dentilis has the spermatodactyl foot slender and toe nodular, whereas these structures are massive and ovate in arenillus.

TyPe Male: Miami, Florida, 24-V-1956, D. De Leon, on Rhus copallina; (MCZ).

Discussion: This species was collected by De Leon at Santurce on Merremia umbellata.

Typhlodromips caobae (De Leon), new combination Amblyseius (Typhlodromips) caobae De Leon, 1965:124 (14).

Diagnosis: T. caobae resembles tennesseensis (De Leon) in having a poculiform cervix but differs in longer dorsal and $L_{8}$ setae and shorter $L_{1}$ and $\mathrm{L}_{4}$.

Type Frmale: Río Piedras, 24-VIII-1963, D. De Leon, on Swietenia mahagoni; (MCZ).

Discussion: Known only from the holotype.

\section{Typhlodromips caribbeanus (De Leon)}

Amblyseius (Typhlodromips) caribbeanus De Leon, 1965:124 (14).

Diagnosis: T. caribbeanus is distinct from other species of Typhlodromips in having Sge IV shorter than Sti IV.

Type Female: El Yunque (elevation about $2500 \mathrm{ft}$.), 26-VIII-1963, D. De Leon, on Psychotria berteriana; (MCZ).

Discussion: This species was also taken in Puerto Rico at Las Croabas by De Leon.

Typhlodromips plumosus Denmark and Muma, new species

Plate I, Figs. 1-5

Diagnosis: $T$. plumosus is similar to tunu: De Leon as both have plumose lateral setae and poculiform spermathecal cervices. T. plumosus has $L_{1}$ about two-thirds as long, $L_{5}$ is about twice as long, $M_{3}$ is about onethird longer, and $\mathrm{L}_{9}$ is about one-fifth longer than tunus.

FEMaLe: Length $270 \mu$; width at $\mathrm{L}_{4} 165 \mu$. Dorsal scutum reticulated with 15 pairs of setae. (Plate I, fig. 1). Measurements of setae: verticals $19 \mu ; D_{1}$ $11 \mu, D_{2} 13 \mu, D_{3} 16 \mu, D_{4} 17 \mu$; clunals $6 \mu ; M_{1} 13 \mu, M_{2} 25 \mu, M_{3} 40 \mu ; L_{1} 20 \mu$, 
$\mathrm{L}_{2} 16 \mu, \mathrm{L}_{3} 27 \mu, \mathrm{L}_{4} 35 \mu, \mathrm{L}_{5} 30 \mu, \mathrm{L}_{6} 17 \mu, \mathrm{L}_{7} 10 \mu, \mathrm{L}_{8} 60 \mu$; anterior sublateral setae $20 \mu$. Posterior sublateral $14 \mu$. Sternal scutum smooth with three pairs of setae (Plate I, fig. 2). Ventrianal scutum smooth with a pair of pores and three pairs of preanal ventrianal setae (Plate I, fig. 2). Peritreme (Plate I, fig. 3) extending forward to the verticals. Chelicerae (Plate I, fig. 5) normal in size, fixed finger with two denticules. Leg formulae 1423. Macrosetae on

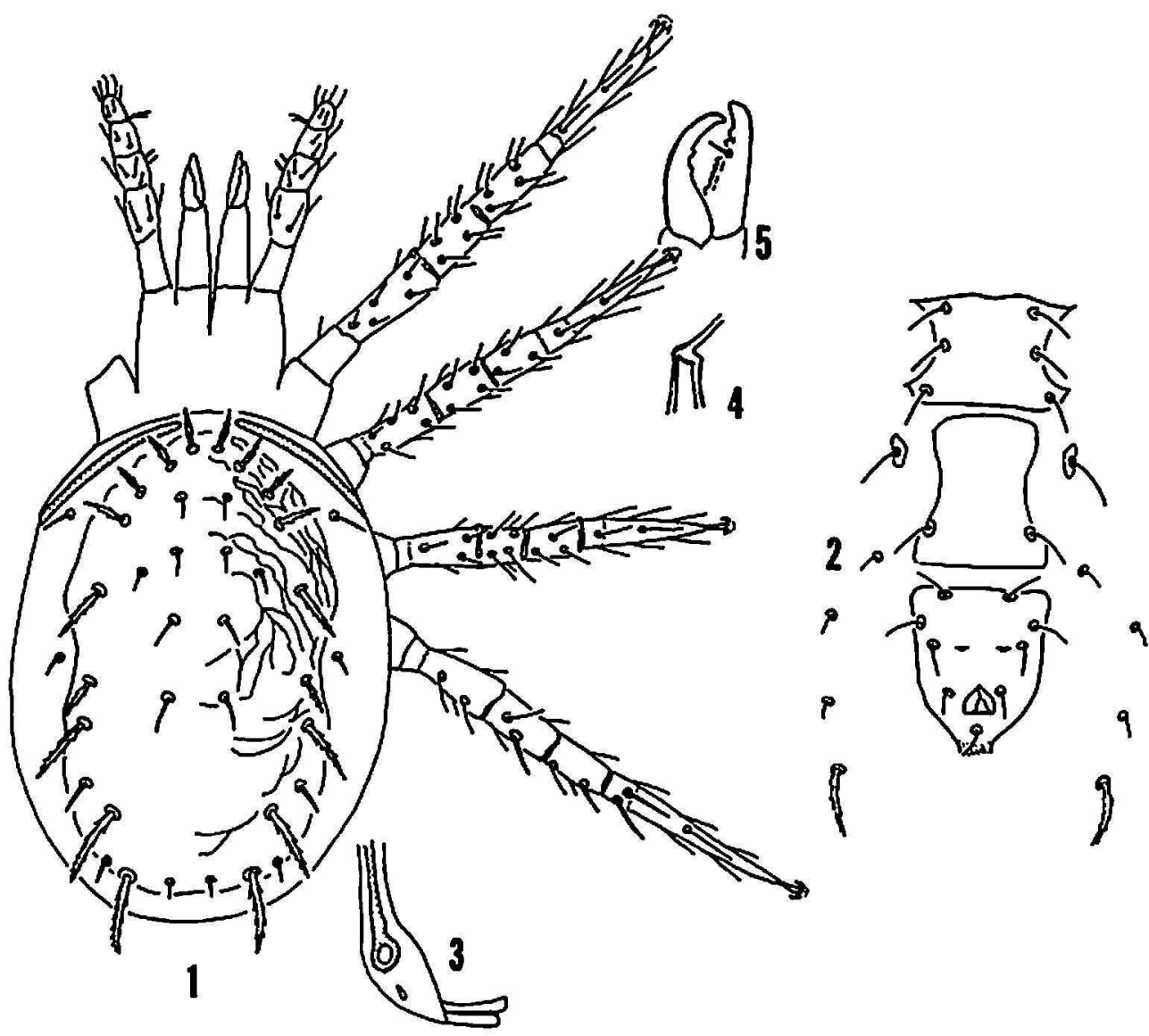

Prate I. Female Typhlodromips plumosus Denmark and Muma, n. sp. Fig. 1. Dorsal and leg structure and setation. Fig. 2. Ventral scuta and setation. Fig. 3. Posterior peritremal and stigmatal development. Fig. 4. Spermathecal structure. Fig. 5. Chelicera.

leg IV as follows: Sge $20 \mu$, Sti $14 \mu$, St $30 \mu$. Genu II $2, \frac{2,2}{1}, 1$; genu III $1, \frac{2,2}{1}$, 1. Spermatheca poculiform (Plate I, fig. 4).

MALE: Unknown.

Type Female: El Yunque, Puerto Rico, 10-V-1969, M. H. Muma, on four-o'clock-like plant; (FSCA).

Discussion: In addition to the holotype, the following paratypes were collected: 1 female, Mameyes-El Yunque, Rd. 1913, Km 11.6, 1-IX-1968, on Elephantopus sp.; 6 females, Barranquitas-Dona Juana Forest, Rd. 140, 
Km 54.5, 29-VIII-1968, on "higuillo"; 1 female with the holotype, EI Yunque, Km 6.6 from Palmer, 10-V-1969, on four-o'clock-like plant.

\section{Typhlodromips mangleae De Leon}

Typhlodromips mangleae De Leon, $1967: 28$ (18).

Diagnosis: T. mangleae is similar to caobae De Leon, but has $\mathrm{M}_{3}$ approximately half as long as $\mathrm{L}_{8} . T$. caobae has $\mathrm{M}_{2}$ equal to $\mathrm{L}_{8}$ and dorsal setae longer than mangleae.

Type Female: Near College Experiment Station Farm, St. Augustine, Trinidad, 23-IX-1963, D. De Leon, on Rhizophora mangle; (MCZ).

Discussion: We have one additional record: 1 female, Mayagüez, 26V- 1969, on unknown host.

\section{Genus Typhlodromalus Muma}

Amblyseius (Typhlodromalus) Muma, 1961:288 (39).

Typhlodromalus, De Leon, 1961:87 (12). Type: Amblyseius peregrinus Muma, 1955, by designation of Muma, 1961.

There are about 15 species in this genus that are widely distributed and especially common in the Caribbean area.

Typhlodromalus yunquensis (De Leon)

Amblyseius (Typhlodromalus) yunquensis De Leon, 1965:124 (14).

Dragnosis: T. yunguensis resembles congeae De Leon but is separated from it by the overall smaller measurements in size and lengths of setae. $\mathrm{M}_{3}$ is approximately one half as long as $\mathrm{L}_{8}$ in yunguensis and approximately three-fourths as long as $\mathrm{L}_{8}$ in congeae.

Type Framale: El Yunque, 26-VIII-1963, D. De Leon, on Clibadium erosum; (MCZ).

\section{Typhlodromalus congeae De Leon}

Amblyseius (Typhlodromalus) congeae De Leon, 1965:125 (14).

Diagnosis: $T$. congeae resembles yunquensis De Leon but is generally a larger species with longer setae. $M_{3}$ is approximately three-fourths as long as $\mathrm{L}_{8}$ in congeae and approximately one half as long as $\mathrm{L}_{8}$ in yunquensis.

Type Female: Río Piedras, 24-VIII-1963, D. De Leon, on Congea tomentosa; (MCZ). De Leon also collected two female paratypes from Río Piedras, 3-IX-1963, on Clerodendron sp.

Typhlodromalus rapax De Leon, new combination Amblyseius (Typhlodromalus) rapax De Leon, 1965:125 (14).

Diagnosis: T. rapax closely resembles limonicus (Garman and McGregor) but differs in size, in the relative lengths of the setae of the dorsal 
scutum, in having a pore near $M_{1}$, in dentition of chelicerae, and in size of the spermatheca.

Type Female: Río Piedras, 24-VIII-1963, D. De Leon, on Lantana involucrata; (MCZ). De Leon also collected two female paratypes from Cayey Mountain, 28-VIII-1963, on Cordia alliodora.

\section{Typhlodromalus peregrinus (Muma)}

Typhlodromus peregrinus Muma, 1955:270 (38); Chant, 1959:97 (5).

Typhlodromus (Amblyseius) robiniae Chant, 1959:98 (5).

Typhlodromus (Amblyseius) primulae Chant, 1959:99 (5).

Amblyseius (Typhlodromalus) peregrinus, Muma, 1961:288 (39).

Typhlodromalus peregrinus, Muma, Denmark, and De Leon, $1970: 88$ (47).

Diagnosis: This species is closely related to $T$. planetarius (De Leon) from Mexico and $T$. olombo (Pritchard and Baker) from Africa. The genitalic details and the relative lengths of setae on the dorsal scutum separate $T$. peregrinus from the above species.

TrPe Frmale: Minneola, Florida, 24-I-1952, M. H. Muma, on scaly citrus leaves; (NMNH).

Discussion: Muma (43) evaluated this species as a predator on citrus insects and mites in Florida. Martorell took specimens of this species at Isabela, Puerto Rico, 5-I-1951, on pepper; it was described as Typhlodromus (Amblyseius) evansi by Chant (5) and synonymized by Muma, Denmark, and De Leon (47).

\section{Typhlodromalus limonicus (Garman and MeGregor)}

Amblyseius limonicus Garman and McGregor, 1956:11 (28).

Typhlodromus (Amblyseius) limonicus, Chant, 1959:96 (5).

Typhlodromalus limonicus, De Leon, $1967: 22$ (18).

Diagnosis: This species is closely related to $T$. horatii De Leon. $L_{1}$ is approximately half the length of $\mathrm{L}_{4}$ in limonicus while $\mathrm{L}_{1}$ is approximately the same length in horatii.

TYPE: The female from Santa Ana, California is in the Connecticut Agricultural Experiment Station collection, New Haven, Connecticut.

Discussion: The biology and food habits of this species were discussed by McMurtry and Scriven (32). Our Puerto Rico records include: 1 female, 1 nymph, Mameyes-El Yunque, Rd. 191, Km 11.6, 1-IX-1968, on unknown host; 2 females, 1 male, Mameyes-El Yunque, Rd. 191, Km 10.4, 1-IX1968, on "higuillo"; 1 female, Mameyes-El Yunque, Rd. 191, 1-IX-1968, on Ipomoea sp.; 2 males, El Yunque, Rd. 191, Km 10.4, 25-V-1969, on unknown host; 1 male, El Yunque, Rd. 191, Km 10.4, 22-V-1969, on unknown host; 1 female, El Yunque, Km 13.4, from Mameyes (Palmer), 10-V-1969, on unknown host; 4 females, 1 male, El Yunque, $\mathrm{Km} 2.9$ toward Luquillo 
through Bo. Sabana on Rd. 191, 25-V-1969, on "higuillo"; 1 female, 1 male, Utuado-Arecibo, Km 63.4, 4-IX-1968, on unknown host; 1 male, Mayagüez, Rd. 106, Km 5.3, 27-V-1969, on coffee leaves.

\section{Typhlodromalus higuilloae Denmark and Muma, new species}

Plate II, Figs. 6-12

Diagnosis: $T$. higuilloae is distinguished from the closely related pregrinus (Muma) in having $\mathrm{L}_{4}$ and $\mathrm{L}_{8}$, genu I with macrosetae, and $\mathrm{M}_{3}$ and $\mathrm{L}_{8}$ not as thick or serrated as in peregrinus.

FEMALE: Length $268 \mu$; width at $\mathrm{L}_{4} 151 \mu$. Dorsal scutum smooth with slight creases along the anterior border and 17 pairs of setae (Plate II, fig. 6). Measurements of setae: verticals $27 \mu ; D_{1} 9 \mu, D_{2} 8 \mu, D_{3} 9 \mu, D_{4} 10 \mu ; M_{1} 7 \mu$, $\mathrm{M}_{2} 9 \mu, \mathrm{M}_{3} 39 \mu$; clunals $6 \mu ; \mathrm{L}_{1} 39 \mu, \mathrm{L}_{2} 13 \mu, \mathrm{L}_{3} 20 \mu, \mathrm{L}_{4} 58 \mu, \mathrm{L}_{5} 16 \mu, \mathrm{L}_{7} 6 \mu, \mathrm{L}_{8}$ $59 \mu$; anterior sublaterals $25 \mu$; posterior sublaterals $8 \mu$. Sternal scutum
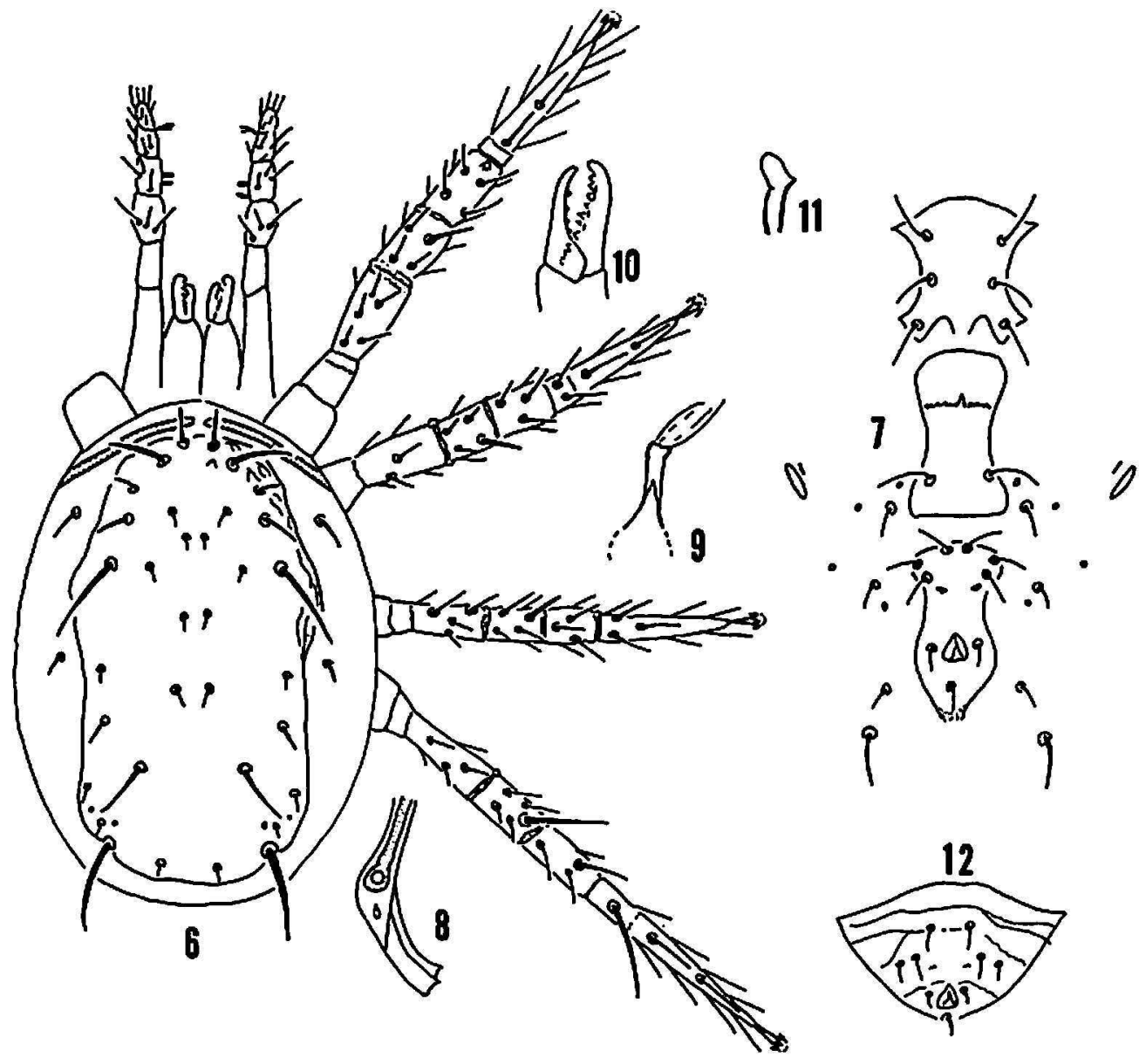

Plate II. Female Typhlodromalus higuilloae Denmark and Muma, n. sp. Fig. 6. Dorsal and leg structure and setation. Fig. 7. Ventral scuta and setation. Fig. 8. Posterior peritremal and stigmatal development. Fig. 9. Spermathecal structure. Fig. 10. Chelicera. Fig. 11. Male spermatodactyl structure. Fig. 12. Male ventrianal scutum. 
(Plate II, fig. 7) smooth with three pairs of setae; the ventrianal scutum (Plate II, fig. 7) smooth with one pair of pores, and three pairs of preanal ventrianal setae. Peritreme (Plate II, fig. 8) extending forward to the verticals. Chelicerae (Plate II, fig. 10) normal fixed finger with 11 to 12 denticules and the movable finger with three to four denticules. Leg formulae 4123. Macrosetae on genu I, II, III. Macrosetae of leg IV as follows: Sge $55 \mu$, Sti $32 \mu$, and St $60 \mu$. Genu I 1, $\frac{2,2}{1}, 2$; genu III $1, \frac{2,2}{1}, 1$. Spermatheca tubular undifferentiated (Plate II, fig. 9).

MaLE: The male is smaller than the female. The ventrianal scutum (Plate II, fig. 12) with three pairs of preanal setae. The spermatodactyl (Plate II, fig. 11) with foot terminal, heel and lateral process distinct, toe broad and flat.

Type Female: El Yunque, Km 13.4 from Palmer, Puerto Rico, 10-V1969, M. H. Muma, on leaves of "higuillo"; (FSCA).

Discussion: One female paratype was collected with the holotype; the allotype male was taken 3 miles southwest of Naval Station on Rd. 973, 31-VIII-1968, on castor bean; three female paratypes were collected at El Yunque, $\mathrm{Km}$ 11.0 from Palmer, 10-V-1969, on leaves of "higuillo".

\section{Genus Euseius Wainstein}

Amblyseius (Amblyseius) section Euseius Wainstein, 1962:15 (58).

Euseius, De Leon, $1966: 86$ (17). Type: Seiulus finlandicus Oudemans, 1915, by designation of Wainstein, 1962 (58).

There are over 40 known species and the genus is world-wide in distribution. It is common on the mainland of North America and in the Caribbean area.

\section{Euseius ho (De Leon), new combination}

Amblyseius (Euseius) ho De Leon, 1965:125 (14).

Diagnosis: $E$. ho closely resembles hum Pritchard and Baker, but differs in having longer anterolateral setae and shorter caudal setae.

Type Female: Coamo, Puerto Rico, 28-VIII-1963, D. De Leon, on Colubrina reclinata; (MCZ).

Drscussion: De Leon took one female and two males with the holotype. He also took a female on Tetrazygia elaeagnoides and a male on Eupatorium odoratum on the same date and location as the holotype. Our records include the following: 4 females, Mayagüez, Rd. 106, Km 5.3, 27-V-1969, on coffee leaves; 1 female, 1 male, Isabela Agr. Exp. Sub-sta., 18-V-1969, on tropical almond; 4 females, 2 males, Mayagüez-Maricao, Rd. 105, Km 12.7, 3-IX1968 , on unknown host. 


\section{Euseius sibelius (De Leon)}

Amblyseius (Typhlodromalus) sibelius De Leon, 1962:21 (13).

Amblyseius (Euseius) subalatus De Leon, 1965:127 (14).

Euseius sibelius, Muma, Denmark, and De Leon, 1970:98 (47).

Diagnosis: E. sibelius is similar to scutalis (Athias-Henriot) but has $\mathrm{L}_{1}$, $\mathrm{L}_{2}, \mathrm{~L}_{4}$, and $\mathrm{L}_{8}$ much shorter, and has knobbed macrosetae on leg IV.

Type Female: Coral Gables, Florida, 3-VI-1956, D. De Leon, on Clerodendron sp.; (MCZ).

Discussion: De Leon collected this species at Juana Díaz, 28-VIII-1963, on Citharexylum fruticosum.

\section{Euseius hibisci (Chant)}

Typhlodromus (Amblyseius) hibisci Chant, 1959:68 (5).

Amblyseius (Typhlodromalus) hibisci, Muma, $1961: 288$ (39).

Euseius hibisci, Muma, Denmark, and De Leon, 1970:94 (47).

DIAGNosis: This species is distinguished from sibelius by having verticals equal $L_{4}$ in length while the verticals are shorter than $L_{4}$ in sibelius. $L_{8}$ is 3 times longer than $\mathrm{M}_{3}$ in hibisci while $\mathrm{I}_{8}$ is twice as long as $\mathrm{M}_{3}$ in sibelius.

Type Female: Alamos, Sonora, Mexico, 6-III-1961, Mr. Crow, on hibiscus leaves; (NMNH).

Discussion: McMurtry and Scriven $(32,33,34,35,36)$ indicated that this is a pollen feeder that can facultatively feed on a wide range of insects and mites. Our Puerto Rican records include: 2 males, Mayagüez, Rd. 106, Km 5.3, 27-V-1969, on coffee leaves; 1 female, Hato Rey, 25-VIII-1969, on coffee leaves; 1 female, Hato Rey, 25-VIII-1968, on grape; 1 female, Hato Rey, 24-VIII-1968, on hibiscus.

\section{Genus Neoseiulus Hughes}

Neoseiulus Hughes, 1948:141 (29); De Leon, $1965: 23$ (16); Muma and Denmark, 1968:235 (45). Type: Neoseiulus barkeri Hughes, 1948 (29) by original designation.

Typhlodromus (Typhlodromopsis) De Leon, 1959:113 (9) (in part). Cydnodromus Muma, 1961:290 (39); Muma, 1967:273 (42).

There are about 40 known species in this genus that have considerable range in their habitat preference. The genus is common in the Caribbean area, although only a single species has been taken in Puerto Rico.

\section{Neoseiulus setulus (Fox), new combination}

Boringuolaelaps setulus Fox, 1947:599 (24).

Diagnosis: Distinguishing characters of this species include a nearly smooth dorsal scutum, subequal dorsal scutal setae and a slender and in- 
distinct but elongate St IV. $N$. setulus is closely related to $N$. marinellus (Muma) but the latter lacks macrosetae on leg IV.

Type Frmale: San Juan (Santurce), Puerto Rico, 4-XI-1946, I. Fox, on Rattus norvegicus; (STM). This species is known only from the type.

\section{PHYTOSEINAE Berlese}

\section{Genus Phytoseius Ribaga}

Phytoseius Ribaga, 1904:177 (51); Muma and Denmark, 1968:229 (45). Type: Phytoseius plumifer (C. and F.), 1876, by subsequent designation of Vitzthum, 1914 (56), based on Ribaga's 1914 (51) description.

Dubininellus Wainstein, 1959:1365 (57).

Pennaseius Pritchard and Baker, 1962:223 (50).

Two subgenera are recognized: Phytoseius Ribaga and Pennaseius Pritchard and Baker. $\mathrm{S}_{2}$ is missing in the subgenus Phytoseius.

\section{Phytoseius (Phytoseius) woodburyi De Leon}

Phytoseius (Phytoseius) woodburyi De Leon, 1965:130 (14).

Diagnosis: $P$. woodburyi is similar to rachelae Swirski and Shechter, but differs in having $\mathrm{L}_{3}$ serrate and dorsal scutum rugose.

Type Fenale: North of Coamo, 28-VIII-1963, D. De Leon, on Licaria salicifolia; (MCZ).

Discussion: This species originally was known only from the holotype. De Leon (unpublished) collected it in Trinidad and Jamaica. Muma collected it in Puerto Rico: 5 females, east of San Juan along Rd. 3, $\mathrm{Km} \mathrm{43.2,}$ 31-VIII-1968, on unknown host; 2 females, Río Piedras, Agr. Exp. Sta., 23-VIII-1968, on star jessamine.

\section{Phytoseius (Phytoseius) rex De Leon}

\section{Plate III, figs. 13-19}

Phytoseius (Phytoseius) rex De Leon, 1967:12 (18).

Diagnosis: $P$. rex is similar to woodburyi De Leon but has an elongate cervix, macrosetae on the genu and the basitarsus longer and $L_{3}$ and $L_{5}$ are shorter. The female is redescribed below and the male is described for the first time.

Female: Length $264 \mu$; width at $\mathrm{L}_{6} 137 \mu$. Dorsai scutum rugose with 15 pairs of setae (Plate III, fig. 13). Measurements of setae: verticals $27 \mu ; D_{1}$, $\mathrm{D}_{2}, \mathrm{D}_{3}$, and $\mathrm{M}_{1} 4 \mu$; clunals $5 \mu ; \mathrm{L}_{1} 41 \mu, \mathrm{L}_{2} 11 \mu, \mathrm{L}_{8} 20 \mu, \mathrm{L}_{4} 7 \mu, \mathrm{L}_{5} 105 \mu, \mathrm{L}_{6} 75 \mu$, $\mathrm{L}_{7} 71 \mu, \mathrm{L}_{8} 71 \mu$; anterior sublateral setae $36 \mu$. Sternal scutum (Plate III, fig. 14) smooth with 2 pairs of setae. Ventrianal scutum smooth with 3 pairs of preanal ventrianal setae (Plate III, fig. 14). Peritreme (Plate III, fig. 15) 
extending forward to the verticals. Chelicerae (Plate III, fig. 17) small, fixed finger of chelicerae with 2 denticules and the movable finger with 1 small denticule. Leg formula 4123. Macrosetae on leg IV as follows: Sge IV $20 \mu$, Sti IV $46 \mu$, and St IV $37 \mu$. Genu II $2, \frac{2,2}{0}, 1$; genu III $1, \frac{2,2}{0}, 1$. Spermatheca (Plate III, fig. 16) fundibuliform nodular.

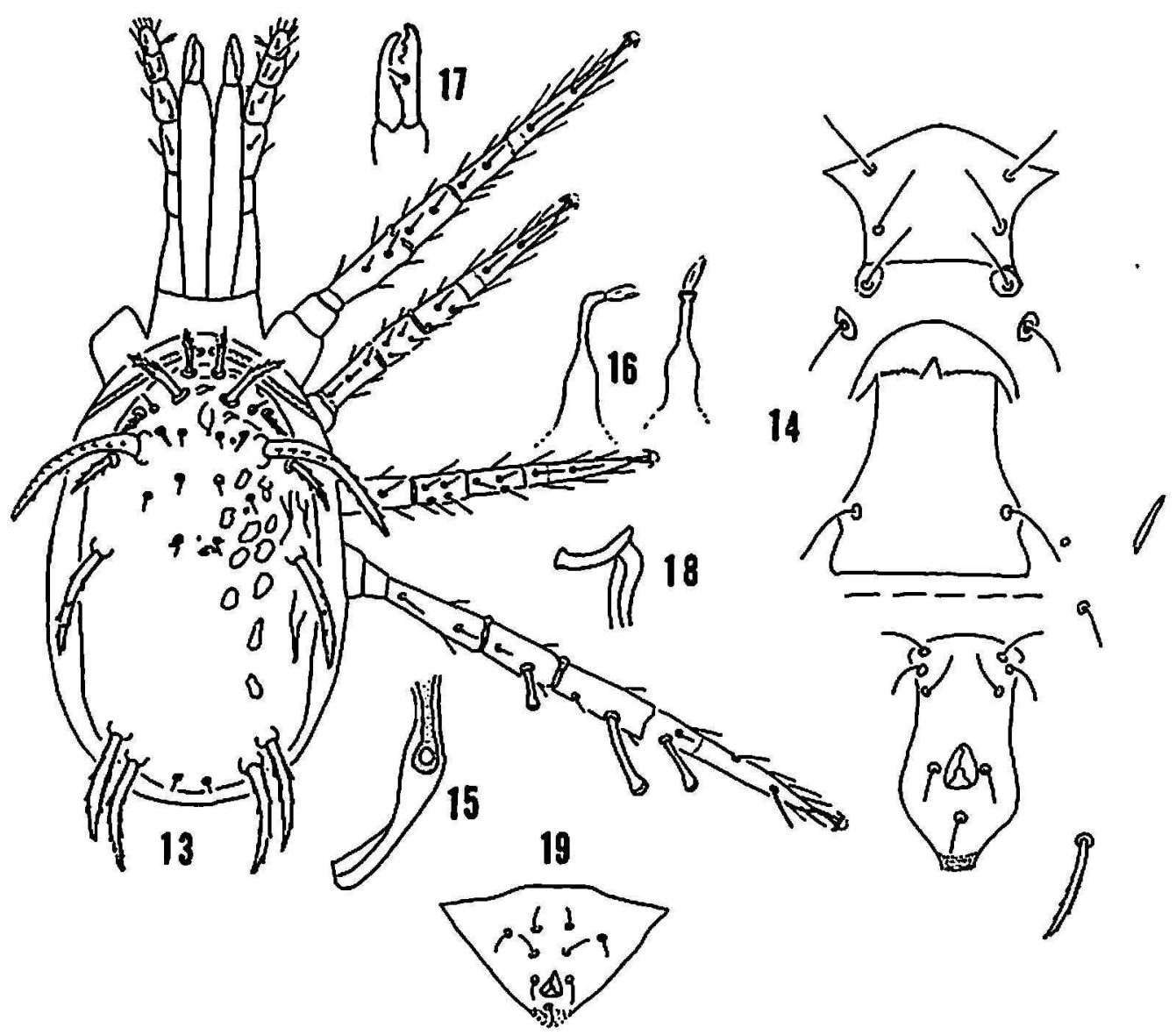

Plate III. Female Phytoseius rex De Leon. Fig. 13. Dorsal and leg structure and setation. Fig. 14. Ventral scuta and setation. Fig. 15. Posterior peritremal and stigmatal development. Fig. 16. Spermathecal structures (two views). Fig. 17. Chelicera. Fig. 18. Male spermatodactyl structure. Fig. 19. Male ventrianal scutum.

MALE: The male is smaller than the female. The ventrianal scutum (Plate III, fig. 19) with 3 pairs of preanal setae. The spermatodactyl (Plate III, fig. 18) has foot terminal.

TyPe Female: Curepe, Trinidad, 23-IX-1963, D. De Leon, on Phaseolus lunatus; (MCZ).

Discussion: Our Puerto Rican records include: 2 females, Río Piedras, Agr. Exp. Sta., 23-VIII-1968, on star jessamine; 2 females, 1 nymph, Hato Rey, 24-VIII-1968, on unknown host; 2 females, 1 nymph, east of San Juan along Rd. 3, Km 55, 31-VIII-1968, on unknown host; 1 male, Sabana Grande-Yauco, Km 225.6, 3-IX-1968, on Rivina humilis. 
Phytoseius (Pennaseius) bennetti De Leon

Phytoseius (Pennaseius) bennetti De Leon, 1965:14 (15); Denmark, 1966:36 (19).

Diagnosis: $P$. bennetti is similar to averrhoae De Leon, but bennetti has pores between $D_{3}$ and $D_{4}$, clunals and $L_{8}$, and $L_{7}$ and $L_{8}$; spermathecal atrium only slightly nodular.

Type Female: Manzanilla Bay, Trinidad, 3-X-1963, F. D. Bennett, on Hibiscus tiliaceus; (MCZ).

Discussion: De Leon collected it in Puerto Rico at Río Piedras, 23-X1963, on Congea tomentosa, and Cayey Mountain on Eupatorium odoratum.

\section{Genus Typhloseiopsis De Leon}

Typhloseiopsis De Leon, 1959:150 (11); Chant 1959:113 (5); Muma 1961: 294 (39); Pritchard and Baker 1962:222 (50); Schuster and Pritchard 1963:205 (52). Type: Typhloseiopsis theodoliticus De Leon, 1959, by original designation.

There are three known species in this genus and these are restricted to Mexico and Puerto Rico.

\section{Typhloseiopsis funiculatus De Leon}

Typhloseiopsis funiculatus De Leon, 1965:122 (14).

Diagnosis: T. funiculatus is similar to theodoliticus De Leon but has ventrianal scutum fully developed and $L_{2}, L_{3}$ and $L_{4}$ minute.

Trpe Female: Coamo, Puerto Rico, 28-VIII-1963, D. De Leon on Gymnanthes lucida; (MCZ).

Discussion: This species is known only from the female holotype.

\section{Genus Diadromus Athias-Henriot}

Diadromus Athias-Henriot, 1960:67 (1); De Leon, 1966:100 (17); Muma, 1961 :294 (39); Denmark and Muma, 1972:27 (21). Type: Typhlodromus contiguus Chant, 1959, by original designation.

Typhloseiopsis De Leon; Muma, 1961 (39) (in part, not type).

Chanteius Wainstein, 1962:11 (58); De Leon, 1967:16 (18).

There are two species in this genus. $D$. contiguus (Chant) has been reported from Hong Kong and regularis is reported from Guyana (formerly British Guiana), Puerto Rico, Trinidad, and Colombia, South America.

\section{Diadromus regularis (De Leon)}

Typhloseiopsis regularis De Leon, 1965:122 (14).

Diadromus regularis, De Leon, 1966:100 (17); Denmark and Muma, 1972:

27 (21).

Chanteius regularis, De Leon, 1967:16 (18). 
Diagnosis: We question whether regularis is congeneric with the genus Diadromus. If it does belong in this genus, it can be separated from $D$. contiguus by the fundibular spermatheca and a deep notch in the dorsal scutum.

Type Female: Cayey Mountain, Puerto Rico, 28-VIII-1963, D. De Leon, on Mangifera indica; (MCZ).

Discussion: De Leon collected 1 female and 2 nymphs with the holo type. Our Puerto Rican records include: 1 female, El Yunque, 7-V-1969, on roseapple leaves; 1 female, $\mathrm{Rd}$. 119, $\mathrm{Km} \mathrm{9.0,} \mathrm{near} \mathrm{intersection} \mathrm{113,} \mathrm{2-IX-}$ 1968 , on unknown host.

\section{Genus Typhlodromina Muma}

Typhlodromina Muma, 1961:297 (39). Type: Iphidulus conspicuus Garman, 1948, by designation of Muma (39).

Muma and Denmark (46) gave a detailed account of the $T$. conspicua species-group which included conspicua (Garman), subtropica Muma and Denmark, eharai Muma and Denmark, and tropica (Chant). The pini group and adjacentis group were also delineated in this report.

\section{Typhlodromina conspicua (Garman)}

Iphidulus conspicuus Garman, 1948:14 (26).

Typhlodromus conspicuus, Nesbitt, $1951: 22$ (48); Chant, 1959:55 (5).

Typhlodromina conspicua, Muma, 1961:297 (39); Muma and Denmark, 1969:407 (46).

DIAGNosis: $T$. conspicua can be separated from the closely related eharai by having the spermathecal cervix 2.5 to 3.5 times longer than wide and ventrianal pores circular and distinct whereas eharai has the spermathecal cervix 2 times longer than wide and the ventrianal pores punctate and indistinct.

Trpe Female: Hamden, Connecticut, 1937, from apple bark, in the Connecticut Agricultural Experiment Station collection at New Haven.

Discussion: This species was taken in Puerto Rico by De Leon at Coamo, 23-VIII-1963, on Sterculia apetala and Tetrazygia elaeagnoides; at Juana Díaz, 23-VIII-1963, on Hura crepitans; at Cayey Mountain (elevation about $1800 \mathrm{ft}$.), 23-VIII-1963, on Cordia sulcata.

\section{Typhlodromina adiacentis (De Leon)}

Typhlodromus adjacentis De Leon, 1959:124 (10).

Typhlodromina adjacentis, De Leon, 1965:121 (14); De Leon 1967:16 (18).

DIAGNOSIS: $T$. adjacentis is readily distinguished from other species by the short dorsal setae, the serrate-oblanceolate $M_{2}$ and $L_{8}$ setae, and the strongly cleft dorsal scutum. 
Type Female: Aticama, Nay, Mexico, 8-IV-1957, D. De Leon on Randia sp.; (MCZ).

Discussion: De Leon collected this species in Puerto Rico at Coamo, 23-VIII-1963, on Sterculia apetala; Cayey Mountain, on Myrcia splendens, Cordia alliodora, and Polypodium phyllitidis; El Yunque (elevation about $2500 \mathrm{ft}$.) on Myrcia deflexa.

\section{Genus Galendromus Muma}

Galendromus Muma, 1961:298 (39). Type: Typhlodromus floridanus Muma, 1955 (38), by subsequent designation, Muma, 1961 (39); Muma, 1963:15 (40); Tuttle and Muma, 1973:30 (55).

Muma (40) revised this genus and recognized 17 species in 3 subgenera. The genus is represented over a wide geographical area ranging from Canada to Mexico, Puerto Rico, Chile and Paraguay.

\section{Galendromus annectens (De Leon)}

Typhlodromus annectens De Leon, 1958:75 (7).

Galendromus annectens, Muma, $1961: 298$ (39); Muma, $1963: 20$ (40); Muma,

Denmark, and De Leon, 1970 (47).

Diagnosis: $T$. annectens is the smallest species in the subgenus Galendromus. The body is $290 \mu$ long and has punctate preanal pores.

Type Female: Coral Gables, Florida, 4-VI-1956, D. De Leon, on Trema micrantha; (MCZ).

Discussion: De Leon collected this species in Puerto Rico at Santurce, 23-VIII-1963, on Hura crepitans, and at Ponce, 23-VIII-1963, on Guazuma ulmifolia. Our Puerto Rican records include: 3 females, Río Piedras, Agr. Exp. Sta. greenhouse, 28-VIII-1968, J. Greene and M. H. Muma, on Cedrella odorata, probably feeding on Tetranychus tumidus Banks.

\section{Galendromus luculentis (De Leon)}

Typhlodromus luculentis De Leon, 1959:126 (10); Herschmann, 1962:14 (30).

Galendromus luculentis, Muma, 1961 :298 (39); Muma, $1963: 36$ (40).

Diagnosis: $G$. luculentis is closely related to carinulatus (De Leon), but is separated from it by the subequal, plumose $M_{2}$ and $L_{8}$ and the absence of preanal pores on the ventrianal scutum.

Type Female: Tuxtla Gutierrez, Chiapas, Mexico, 11-I-1957, D. De Leon on Guazuma tomentosa; (MCZ).

Discussion: Our Puerto Rican records include: 1 male, 1 nymph, El Yunque, Luquillo Rd., Caribbean National Forest, Km 5.5, 26-VIII1968, on turk's cap; 3 females, Mameyes-El Yunque, Rd. 191, Km 11.6, 1-IX-1968, on unknown host; 1 female, 1 male, El Collao, Cayey-Salinas 
Rd., Km 71.0, 27-VIII-1968, on turk's cap; 2 females. El Yunque on Rd. 191, $\mathrm{Km}$ 10.4, 25-V-1969, on unknown host.

\section{Genus Amblydromella Muma}

Amblydromella Muma, $1961: 294$ (39). Type: Typhlodromus fleschneri Chant, 1960 by designation of Muma, 1961 (39); Muma, $1967: 276$ (42). Typhlodromella Muma, $1961: 299$ (39).
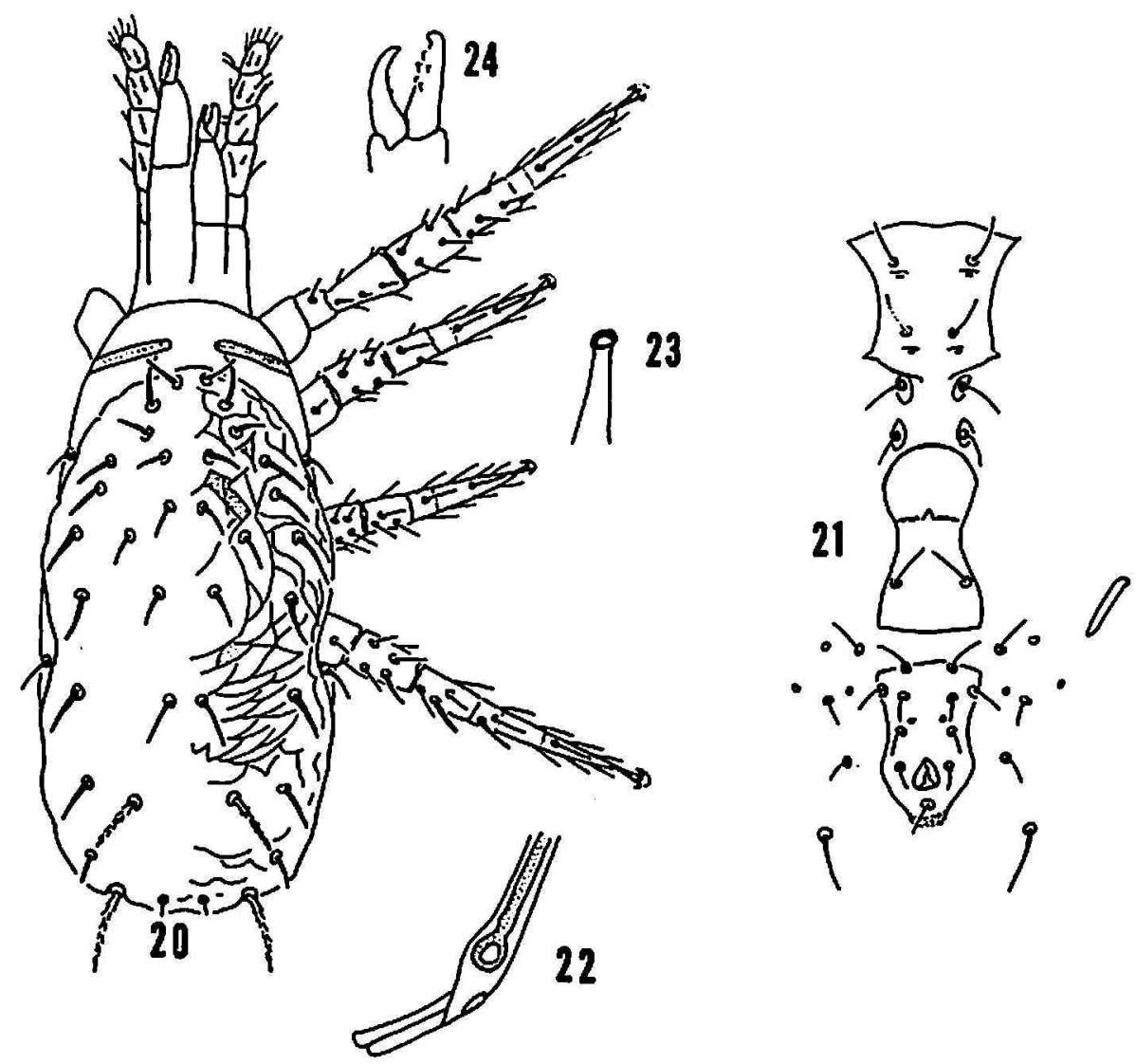

Plate IV. Female Amblydromella deleoni Denmark and Muma, n. sp. Fig. 20. Dorsal and leg structure and setation. Fig. 21. Ventral scuta and setation. Fig. 22. Posterior peritremal and stigmatal development. Fig. 23. Spermathecal structure. Fig. 24. Chelicera.

Muma (42) discussed two groups of species belonging to this genus and cited species to which no group assignment could be made. The new species described in this paper also cannot be assigned to a species group.

Amblydromella deleoni Denmark and Muma, new species

\section{Plate IV, Figs. 20-24}

Diagnosis: $A$. deleoni can be separated from loralaiana Muma by the small macrosetae on leg IV and longer $\mathrm{L}_{9}$.

FEMALE: Length $299 \mu$; width at $L_{6} 160 \mu$. Dorsal scutum reticulated and 
18 pairs of setae (Plate IV, fig. 20). Measurements of setae: verticals $19 \mu$; $\mathrm{D}_{1}$ and $\mathrm{D}_{2} 17 \mu, \mathrm{D}_{3} 20 \mu, \mathrm{D}_{4} 25 \mu$; clunals $8 \mu ; \mathrm{M}_{1} 17 \mu, \mathrm{M}_{2} 35 \mu ; \mathrm{L}_{1} 25 \mu, \mathrm{L}_{2} 18 \mu$, $\mathrm{L}_{3} 22 \mu, \mathrm{L}_{4} 22 \mu, \mathrm{L}_{5} 25 \mu, \mathrm{L}_{6} 28 \mu, \mathrm{L}_{7} 30 \mu, \mathrm{L}_{8} 27 \mu, \mathrm{L}_{9} 17 \mu, \mathrm{L}_{10} 47 \mu$; anterior sublateral setae $25 \mu$, posterior sublateral setae $23 \mu$. Sternal scutum (Plate IV, fig. 21) smooth, with 2 pairs of pores and 2 pairs of setae. Ventrianal scutum (Plate IV, fig. 21) smooth with a pair of pores and 4 pairs of preanal ventrianal setae. Peritreme (Plate IV, fig. 22) extending forward to the verticals. Chelicerae (Plate IV, fig. 24) normal in size, fixed finger with 5 denticules, movable finger with 2 very small denticules. Leg formulae 1423. Macrosetae on leg IV: Sge $10 \mu$, Sti $13 \mu$, St $20 \mu$. Genu II $1, \frac{2,2}{0}, 1$; genu III $1, \frac{2,2}{0}, 1$. Spermatheca (Plate IV, fig. 23) fundibuliform nodular.

\section{MALE: Unknown.}

Type Female: Sabana Grande to Yauco Road, Puerto Rico, 3-IX1968, M. H. Muma, on Rivina humilis; (FSCA). One nymph was taken at Río Piedras, Puerto Rico, Agr. Exp. Sta., 23-VIII-1968, M. H. Muma on star jessamine.

\section{RESUMEN}

Este articulo es un resumen de los acarinos (Phytoseiidae) de Puerto Rico. En el se describen tres nuevas especies a saber: Typhlodromips plumosus, Typhlodromalus higuilloae y Amblydromella deleoni. Unas catorce especies se informan por primera vez de Puerto Rico, elevando a 48 el número total de especies conocidas.

\section{LITERATURE CITED}

1. Athias-Henriot, C., Phytoseiidae et Aceosejidae (Acarina: Gamasina) d'Algerie, IV Genre Typhlodromus Schueten, 1857, Bul. Soc. Hist. Nat. l'Afrique du Nord 51(1/3): 62-107, 1860.

2. Banks, N., Descriptions of some new mites, Proc. Entomol. Soc. Wash. 7(2/5): 133-42, 1905.

3. - The acarina of mites, U. S. Dept. Agr. Rep. 108: 1-153, 1915.

4. Berelese, A., Acari nuovi, Redia 10 (I \& II) : 113-150, 1914.

5. Chant, D. A., Phytoseiid mites (Acarina: Phytoseiidae), Part I. Bionomics of seven species in southeastern England, Part II. A taxonomic review of the family Phytoseiidae, with descriptions of 38 new species, Can. Ent. 91 (Suppl. 12): 1-166, 1959.

6. Cunliffe, F., and Baker, E. W., A guide to the predatory phytoseiid mites of the United States, Pinellas Biol. Lab. Pub. No. 1: 1-28, 1953.

7. De Leon, D., Four new Typhlodromus from southern Florida, Fla. Ent. 41(2): 73-76, 1958.

8. - - Two new Typhlodromus from Florida (Acarina: Phytoseiidae), Ent. News 60(4): 105-08. 1959.

9. - Seven new Typhlodromus from Mexico with collection notes on three other species (Acarina: Phytoseiidae), Fla. Ent. 42(3): 113-121, 1959.

10. - The genus Typhlodromus in Mexico (Acarina: Phytoseiidae), Fla. Ent. 42(3): 123-29, 1959. 
11. - A new genus and three new species of phyotseiid mites from Mexico with collection records on Phyloseius plumifer (C. \& F.) and P. macropilis (Banks), Ent. News 60(6) : 147-152, 1959.

12. —, Eight new Amblyseius from Mexico, Fla. Ent. 44(2): 85-91, 1961.

13. - - Twenty-three new phytoseiids, mostly from southeastern United States (Acarina: Phytoseiidae), Fla. Ent. 45(1): 11-27, 1962.

14. - Phytoseiid mites from Puerto Rico with descriptions of new species (Acarina: Mesostigmata), Fla. Ent. 48(2): 121-31, 1965.

15. - - Ten new species of Phyloseius (Pennaseius) from Mexico, Trinidad, and British Guiana with a key to species (Acarina: Phytoseiidae), Ent. News 66(1): 13-21, 1965.

16. - A note on Neoseiulus Hughes 1948 and new synonymy (Acarina: Phytoseiidae), Proc. Ent. Soc. Wash. 67(1): 23, 1965.

17. - - Phytoseiidae of British Guyana with keys to species (Acarina: Mesostigmata), In Studies on the Fauna of Suriname and Other Guyanas 8: 81-102, 1966.

18. - Some mites of the Caribbean area; Part I. Acarina on plants in Trinidad, West Indies, Allen Press Incorporated, 1-66, 1967.

19. Denmark, H. A., Revision of the genus Phytoseius Ribaga, 1904 (Acarina: Phytoseiidae), Fla. Dept. Agr. Div. Plant Ind. Bul. 6: 1-105, 1966.

20. - , and Muma, M. H., Ricoseius loxocheles (Acarina: Phytoseiidae), Fla. Ent. 53(2): 119-121, 1970.

21. - and - Some phytoseiid mites of Colombia (Acarina: Phytoseiidae), Fla. Ent. 55(1) : 19-29, 1972.

22. Evans, G. O., On a new predatory mite of economic importance, Bul. Ent. Res. 43(2) : 397-401, 1952.

23. Fox, I., A new genus, Borinquolaelaps, and new species of mites from rats in Puerto Rico, J. Parasitol. 32(5): 445-452, 1946.

24. - Seven new mites from rats in Puerto Rico, Ann. Ent. Soc. Amer. 40(4): 598-603, 1947.

25. - - Five new mites from rats in Puerto Rico, Fla. Ent. 32(1): 37-40, 1949.

26. Garman, P., Mite species from apple trees in Connecticut, Bul. 520, Conn. Agr. Exp. Sta., 1948.

27. - New species belonging to the genera Amblyseius and Amblyseiopsis with keys to Amblyseius, Amblyseiopsis, and Phytoseiulus, Ann. Ent. Soc. Amer. 51(1): 69-79, 1958.

28. - , and McGregor, E. A., Four new predaceous mites (Acarina: Phytoseiidae), Bul. So. Calif. Acad. Sci. 55(1): 7-13, 1956.

29. Hughes, A. M., The mites associated with stored food products, Min. Agr. Fish., London, H. M. Stationery Office, 1-168, 1948.

30. Hirschmann, W., Gamasiden, Schrift. Vergl. Milbenkunde, 1-56, 1962.

31. Koch, C. L., Deutschlands Crustaceen, Myriapoden, und Archniden, Regensburg, 1839.

32. McMurtry, J. A., and Scriven, G. T., Studies of the feeding, reproduction, and development of Amblyseius hibisci (Acarina: Phytoseiidae) on various food substances, Ann. Ent. Soc. Amer. 57(5) : 649-55, 1964.

33. - - and - Life history studies of Amblyseius limonicus, with comparative observations on Amblyseius hibisci (Acarina: Phytoseiidae), Ann. Ent. Soc. Amer. 58(1): 106-11, 1965. 
34. - and - The influence of pollen and prey density on the number of prey consumed by Amblyseius hibisci (Acarina: Phytoseiidae), Ann. Ent. Soc. Amer. 59(1): 147-9, 1966.

35. - - and - Studies on predator-prey interactions between Amblyseius hibisci and Oligonychus punicae (Acarina: Phytoseiidae, Tetranychidae) under greenhouse conditions, Ann. Ent. Soc. Amer. 59(4) : 793-800, 1966.

36. - - and - Studies on predator-prey interactions between Amblyseius hibisci and Oligomychus punicae: effects of host-plant conditioning and limited quantities of an alternate food, Ann. Ent. Soc. Amer. (61(2): 393-7, 1968.

37. van der Merwe, G. G., South African Phytoseiidae (Acarina) 1. Nine new species of the genus Amblyseius Berlese, J. Ent. Soc. South Afr. 28(1): 57-76, 1965.

38. Muma, M. H., Phytoseiidae (Acarina) associated with citrus in Florida, Ann. Ent. Soc. Amer. 48(4): 262-72, 1955.

39. - Subfamilies, genera and species of Phytoseiidae (Acarina: Mesostigmata), Bul. Fla. State Mus. 5(7): 267-302, 1961.

40. - The genus Galendromus Muma, 1901 (Acarina: Phytoseidae), Fla. lint. Suppl. $1: 15-41,1963$.

41. - - Eight new phytoseiids (Acarina: Mesostigmata) from Florida, Fla. Ent. 48(4): 245-254, 19165.

42. - - New Phytoseiidae (Acarina: Mesostigmata) from southern Asia, Fla. Ent. $50(4): 267-80,1967$.

43. - - Typhlodromus peregrinus (Muma) (Acarina: Phytoseiidae) on Florida citrus, Proc. 2nd Intl. Congr. Acarology, Akademiai Kiado, Budapest, pp. 135-48, 1969.

44. - - Food habits of Phytoseiidae (Acarina: Mesostigmata) including common species on Florida citrus, Fla. Ent. 54(1): 21-34, 1971.

45. - - and Denmark, H. A., Some generic descriptions and name changes in the family Phytoseiidae (Acarina: Mesostigmata), Fla. Ent. 51(3): 229-240, 1968.

46. - - and - The conspicua species group of Typhlodromina Muma, 1961 (Acarina: Phytoseiidae), Ann. Ent. Soc. Amer. 62(2): 406-J3, 1969.

47. — - - - and De Leon, D., Phytoseiidae of Florida, Arthropods of Florida and Neighboring Land Areas 6: 1-150, 1970.

48. Nesbitt, H. H. J., A taxonomic study of the Phytoseiinae (Family Laelaptidae) predaccous upon Tetranychidae of economic importance, Zoologische Verhandelingen., 12: 1-64, 1951.

49. Prasad, V., Biology of the predatory mite, Phyloseiulus macropilis, in Hawaii (Acarina: Phytoseiidae), Ann. Ent. Soc. 60(5): 905-8, 1967.

50. Pritchard, A. E., and Baker, E. W., Mites of the family Phytoseiidae from central Afriea, with remarks on the genera of the world, Hilgardia 33(7): 205-309, 1962.

51. Ribaga, C., Gamasidi planticoli, Riv. Pat. Veg. 10: 175-178, 1904.

52. Schuster, R. O., and Pritchard, A. E., Phytoseiid mites of California, Hilgardia $34(7): 19-285,1963$.

53. Smith, L. M., and Siummers, F. M., The structure and biology of the red spider predator, "Hypoaspis" macropilis (Banks), Proc. Ent. Soc. Wash. 51(5) : 209$218,1949$.

54. Swirski, L., and Shechter, R., Some phytoseiid mites (Acarina: Phytoseiidae) of Hong Kong, with a description of a new genus and seven new species, Israel J. Agr. Res. $11(2):$ 97-117, 1961. 


\section{4}

55. Tuttle, D. M., and Muma, M. H., Phytoseiidae (Acarina: Mesostigmata) inhabiting agricultural and other plants in Arizona, Univ. Ariz. Agr. Exp. Sta. Tech. Bul. 208, 1-55, 1973.

56. Vitzthum, G. H. von., Acarina, In Bronns Kllassen und Ordnungen des Tierreichs 5(4) : 767-768, 1941.

57. Wainstein, B. A., A new subgenus and species of the genus Phytoseius Ribaga, 1904 (Phytoseiidae, Parasitiformes). Zool. Zhurn. 38: 1361-65, 1959.

58. - - Revision du genre Typhlodromus Scheuten, 1857 et systematique de la famille des Phytoseiidae (Berlese, 1916) (Acarina: Parasitiformes), Acarologia 4: 5-30, 1962. 